\title{
New Opportunities
}

\section{for Producing Rare Earth Elements One of the Arctic Raw Material Source}

\author{
Alexander V. Tolstov ${ }^{a^{*}}$, \\ Nikolay P. Pokhilenko and Nikolay Yu. Samsonov ${ }^{\mathrm{b}}$ \\ ${ }^{a}$ V.S. Sobolev Institute of Geology and Mineralogy SB RAS \\ 3 Akademika Koptyuga Str., Novosibirsk, 630090, Russia \\ ${ }^{b}$ Institute of Economics and Industrial Engineering SB RAS \\ 17 Akademika Lavrenteva Str., Novosibirsk, 630090, Russia
}

Received 28.02.2017, received in revised form 10.03.2017, accepted 23.03.2017

\begin{abstract}
Russia has unique resources of rare-earth metals, which are capable to satisfy any internal needs of the country and provide access to export. A special place in the raw material base of rare-earth metals, especially because of the unique parameters of ore content takes Tomtor field (north-west of Yakutia). The paper presents an approach justifying the priority development of certain parts of the site Burannyi (Western flank), a unique fortified scarce and the most liquid and expensive rare earth element - heavy lanthanides of the yttrium group. In addition to the developed hydrometallurgical technology an alternative opinion of a full line of rare earth products from a single raw material source is offered. For the first time authors show the possibility of separation of the original ore electrofusion metal (ferroniobium) and clinker, from which rare-earth concentrate can be isolated by mechanical methods for hydrometallurgy and obtained all the REE line.
\end{abstract}

Keywords: rare and rare earth metals, Tomtor, Arctic, electrofusion, Ferroniobium, REE-clinker.

DOI: $10.17516 / 1998-2836-0012$.

(c) Siberian Federal University. All rights reserved

* Corresponding author E-mail address: tolstov@igm.nsc.ru 


\title{
Новые возможности
}

\section{получения редкоземельных элементов \\ из единого арктического сырьевого источника}

\author{
А.В. Толстов ${ }^{\text {a }}$ Н.П. Похиленко ${ }^{\text {a }}$ Н.Ю. Самсонов ${ }^{\tilde{\sigma}}$ \\ ${ }^{a}$ Институт геологии и минералогии \\ им. В.С. Соболева СО РАН \\ Россия, 630090, Новосибирск, пр. Академика Коптюга, 3 \\ ${ }^{6}$ Институт экономики \\ и организаџии промышленного производства СО РАН \\ Россия, 630090, Новосибирск, пр. Академика Лаврентьева, 17
}

\begin{abstract}
Россия обладает уникальными ресурсами редкоземельных металлов (РЗМ), которые способны обеспечивать любые внутренние потребности страны и выход на экспортные поставки. Особое место в сырьевой базе РЗМ, прежде всего, из-за уникальных параметров рудоносности занимает Томторское месторождение (северо-запад Якутии). В статье представлен подход, обосновывающий первоочередное освоение отдельных частей участка Буранный (западный фланг), уникально обогащченных дефиц̧итными и наиболее ликвидными и дорогостоящими редкоземельными элементами - тяжельми лантаноидами иттриевой группь. Помимо разработанной гидрометаллургической технологии предложен альтернативньй вариант получения всей линейки РЗМ продукичии из единого сырьевого источника. Впервые показана возможность разделения исходной руды электроплавкой на металл (феррониобий) и шлак, из которого механическими методами может быть выделен РЗМ-концентрат для гидрометаллургии и получения всей линейки РЗМ.
\end{abstract}

Ключевые слова: редкие и редкоземельные элементы, Томторское месторождение, Арктика, электроплавка, феррониобий, РЗМ-илак.

\section{Постановка \\ проблемной ситуации}

Редкоземельные металлы - группа химических элементов, включавшая в разные годы до половины таблицы Д.И. Менделеева, но главными составляющими ее всегда оставались лантаноиды (химические элементы от La до Lu), а также Y и Sc (табл. 1).

Редкие и редкоземельные металлы (РМ и РЗМ) обладают уникальными физикохимическими свойствами и востребованы в производстве высокотехнологичной продукции. РЗМ используются в виде соединений неразделенных металлов (оксиды, нитраты, фториды, хлориды, карбонаты, силициды, мишметаллы), а также в виде индивидуальных высокочистых и сверхвысокочистых металлов. Главные сферы их использования - сверхсильные магниты (23\%), катализаторы (18 \%), металлургия (11 \%), полириты (14 \%), NiMH-аккумуляторные батареи (10\%), высококачественная оптика и стекло (8 \%), люминофоры и пигменты (8 \%), кера- 
Таблица 1. Систематика редкоземельных металлов [1]

\begin{tabular}{|c|c|c|c|c|c|c|c|c|c|c|c|c|c|c|c|}
\hline \multicolumn{16}{|c|}{ Редкоземельные металлы (P3M) TR REE $=\mathrm{Ln}+\mathrm{Y}+\mathrm{Sc}$} \\
\hline \multicolumn{4}{|c|}{$\begin{array}{c}\text { Цериевая группа } \\
\text { TRCe }\end{array}$} & \multicolumn{12}{|c|}{ Иттриевая группа TRY } \\
\hline \multicolumn{14}{|c|}{ Лантаноиды Ln } & \multirow{3}{*}{$\begin{array}{l}\text { Y (ит- } \\
\text { трий) }\end{array}$} & \multirow{3}{*}{$\begin{array}{c}\mathrm{Sc} \\
\text { (скан- } \\
\text { дий) }\end{array}$} \\
\hline & рие & e- & & & & & & грие & ые - & & & & & & \\
\hline \multicolumn{4}{|c|}{ Легкие LnCe (LREE) } & \multicolumn{6}{|c|}{ Средние LnSm (MREE) } & \multicolumn{4}{|c|}{$\begin{array}{c}\text { Тяжелые LnEr } \\
\text { (HREE) }\end{array}$} & & \\
\hline $\mathrm{La}$ & $\mathrm{Ce}$ & $\operatorname{Pr}$ & $\mathrm{Nd}^{1}$ & $\mathrm{Sm}$ & $\mathrm{Eu}$ & Gd & $\mathrm{Tb}$ & Dy & Ho & Er & $\mathrm{Tm}$ & $\mathrm{Yb}$ & $\mathrm{Lu}$ & & \\
\hline 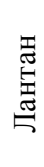 & 兽 & 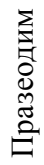 & 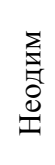 & 胥 & 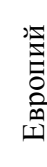 & 莺 & 装 & 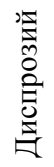 & 罗 & 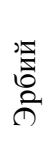 & $\stackrel{\text { 资 }}{\stackrel{5}{5}}$ & 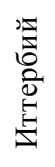 & 恣 & Y & Sc \\
\hline
\end{tabular}

${ }^{1}$ В периодической системе элементов за $\mathrm{Nd}$ следует прометий $(\mathrm{Pm})$, который получен пока только в искусственных условиях.

мика (4 \%) [2]. Основные перспективные и быстрорастущие области применения РЗМ связаны с производством электро- и гибридных автомобилей, ветроэнергетических генераторов, телекоммуникационной, компьютерной, оптической техники, автокатализаторов и катализаторов для крекинга нефти, лазеров, сверхпроводников, топливных элементов. РЗМ включены в технологические цепочки производства высокоточного оружия и военной техники. Значительное влияние на объемы потребления РЗМ в мире оказывает дальнейшее развитие атомной промышленности. Открытие новых направлений использования редких металлов и редкоземельных элементов (РЗЭ) способствует дополнительному росту спроса на них, постепенно изменяет баланс в традиционных областях применения и формирует на мировом рынке профицит P3Э цериевой группы ( $\mathrm{La}, \mathrm{Ce})$ и недостаток других элементов $(\mathrm{Nd}, \mathrm{Eu}, \mathrm{Dy}$ и в целом металлов иттриевой группы).

Мировой рынок РЗМ растет быстрыми темпами: за последние 50 лет его объем увеличился более чем в 25 раз (с 5 до 130 тыс. т в год). Потребление в мире оценивается сегодня на уровне 130 тыс. т $\mathrm{TR}_{2} \mathrm{O}_{3}$ (суммы оксидов) Р3М в год. К 2020 г. объем спроса может вырасти еще примерно в 1,5 раза и достигнет 185-200 тыс. т в год [3-5]. До 90 \% редкоземельных элементов будет производиться в Китае с учетом того, что в настоящее время он контролирует свыше 40 \% их мировых запасов.

В начале нового века рынок характеризовался неуклонным ростом потребления РМ и РЗМ с некоторым дисбалансом между ними то в сторону превышения предложения (до 2009 г.), то существенного опережения спроса (с 2010 по 2012 г.). Это стимулировало неуклонное производство РЗМ: только за первое десятилетие нового века потребление $\mathrm{Nb}$ выросло в 2 раза, что обусловило соответствующий рост его производства, а потребление некоторых РЗМ за этот период выросло в 3-4 раза и продолжает увеличиваться. Наиболее дефицитными из Р3Э являются $\mathrm{Nd}, \mathrm{Pr}, \mathrm{Tb}, \mathrm{Dy}, \mathrm{Eu}$ и Er. Так, расширение производства в мире электро- и гибридных автомобилей (большинство мировых автоконцернов уже выпускают такие автомобили) предопределяет постоянное повышение спроса на $\mathrm{Nd}$. Доля $\mathrm{Nd}$ в потреблении РЗО в 2015 г. составила $20,9 \%$, а в 2020 г. достигнет $26,3 \%$. При его усредненном содержании в перерабатываемом

$$
-127-
$$


Alexander V. Tolstov, Nikolay P. Pokhilenko... New Opportunities for Producing Rare Earth Elements One of the Arctic...

Таблица 2. Баланс спроса и предложения РЗМ в 2015 г. (оценка Roskill Information Service Ltd. и IMCOA)

\begin{tabular}{|c|c|c|c|}
\hline Р3О & Спрос, тыс. т Р3О & Предложение, тыс. т Р3О & $\begin{array}{c}\text { Избыток (+), дефицит (-), } \\
\text { тыс. т }\end{array}$ \\
\hline Всего & 180,0 & 208,5 & $+28,5$ \\
\hline $\mathrm{Ce}$ & $63-68$ & $80-85$ & $+17,0$ \\
\hline $\mathrm{Nd}$ & $35-40$ & $30-35$ & $-5,0$ \\
\hline $\mathrm{Eu}$ & $0,725-0,745$ & $0,575-0,625$ & $-0,12(0,15)$ \\
\hline $\mathrm{Tb}$ & $0,45-0,5$ & $0,375-0,425$ & $+0,075$ \\
\hline $\mathrm{Dy}$ & $2,5-3,0$ & $1,6-2,0$ & $-0,900(0,1)$ \\
\hline
\end{tabular}

сырье в 14-17 \% (в основном, из китайского месторождения Баюнь-Обо) это создаст дефицит Nd в 20,1 тыс. т.

В комплексных редкоземельных рудах, имеющих большой разброс содержаний каждого из элементов, учитывая обычное преобладание легких лантаноидов, их всегда добывается больше, чем РЗМ средней и тяжелой групп. Несмотря на то, что и потребление металлов цериевой группы по массе весьма значительно, стоимость La, Ce, Pr гораздо ниже, чем лантаноидов иттриевой группы. При этом практически всегда наблюдается дефицит одних РЗМ при избытке других. К примеру, для покрытия указанных выше потребностей мирового рынка в $\mathrm{Nd}$ общее производство оксидов РЗМ необходимо в ближайшие годы увеличить до 253 тыс. т, но в этом случае другие P3M, преимущественно La и Ce, будут в избытке в объеме примерно в 20 тыс. т (их рынок к настоящему времени уже перенасыщен). В табл. 2 показан примерный баланс спроса и предложения РЗМ, существовавший в 2015 г.

Таким образом, дефицит определенной части TR будет наблюдаться и в будущем. Учитывая значительные мировые запасы сырья, постепенный переход ряда стран на собственные источники РЗМ, стимулирование предложения спросом, стабильный рынок и сбалансированную ценовую конъюнктуру без «шоковых» ситуаций, серьезных проблем с обеспечением потребностей РЗМ мировой индустрии не стоит ожидать. Главный вопрос для новых сырьевых источников РЗМ, в том числе и российских, - их компонентный редкоземельный состав, который индивидуален для каждого объекта, учет которого при эксплуатации месторождений позволяет контролировать получение оптимальной структуры редкоземельных элементов.

В статье обосновывается подход, показывающий новые возможности первоочередного освоения отдельных частей уникального арктического источника редкоземельных металлов и ниобия (Томторское месторождение), уникально обогащенных дефицитными и наиболее ликвидными и дорогостоящими редкоземельными элементами - тяжелыми лантаноидами иттриевой группы. Помимо разработанной гидрометаллургической технологии переработки редкоземельной руды предложен альтернативный вариант получения всей линейки РЗМ продукции из единого сырьевого источника. Впервые показана возможность разделения исходной руды электроплавкой на металл (феррониобий) и шлак, из которого механическими методами может быть выделен РЗМ-концентрат для гидрометаллургии и получения всей линейки Р3М. 


\section{Ситуация с РМЗ в России}

Россия на глобальном рынке РЗМ пока занимает очень скромные позиции. В СССР потребление этих металлов составляло около 8 тыс. т в год. Одна из проблем развития в России производства редкоземельных металлов - это низкий уровень их потребления. По данным Министерства промышленности и торговли РФ, он оценивается в пределах 1-1,1 тыс. т в год (вероятно, с учетом латентного потребления его можно оценить до 2 тыс. т). Парадокс - Россия занимает второе место в мире по подтвержденным запасам РЗМ, но производство их внутри страны составляет лишь около $2 \%$, а потребление - менее 1 \% от мирового производства и потребления соответственно.

Поскольку возможности по разделению РЗМ в нашей стране мизерные, отечественные предприятия закупают РЗМ и их соединения исключительно за рубежом, в основном в Китае. Добыча редкоземельной руды в России в весьма ограниченных объемах ведется только на Ловозерском месторождении (Ловозерский ГОК, Мурманская область) с получением и переработкой на Соликамском магниевом заводе (Пермская область) лопаритового концентрата. Получаемые карбонаты редкоземельных оксидов практически в полном объеме экспортируется в Казахстан и Эстонию. С 2016 г. начата переработка апатитовых концентратов месторождения «Олений ручей» Хибинской группы месторождений (Мурманская область) на заводе холдинга «Акрон» в Великом Новгороде, но объемы получения оксидов РЗМ весьма незначительны.

Обеспечение промышленного производства России собственными РМ и РЗМ носит стратегически важный характер для национальной безопасности и является важным условием модернизации отечественной промышленности и ее инновационной направленности, опережающего развития технологий, в том числе в военно-промышленной сфере. С учетом ВПК в ближайшие 10 лет потребность в РЗМ в России должна вырасти до показателя базового сценария в 6,8 тыс. т (из общего объема производства в 15-20 тыс. т). Из этого объема 80-90 \% составят La, $\mathrm{Ce}, \mathrm{Pr}, \mathrm{Nd}$ и Y; 9-15 \% придется на Sm, Eu, Gd, Tb, Dy, но и 1-5 \% - на Er, Tm, Yb, Lu. Для этого в России подготовлена уникальная сырьевая база РЗМ мирового уровня: Чуктуконское ( $\mathrm{Nb}$ и РЗМ, Красноярский край), Катугинское (Та и РЗМ, Забайкальский край) и Томторский рудный узел (Nb-Sc-P3М, Якутия). Запасы в России - 28 млн т $\mathrm{TR}_{2} \mathrm{O}_{3}$, т. е. примерно $20 \%$ от известных мировых запасов, причем с учетом неизученного и нераскрытого потенциала Россия признана лидирующей страной по их ресурсам [6-8].

\section{Варианты решения проблемы}

Обеспечение промышленности России Р3-продукцией возможно за счет нескольких направлений. Первое - задействование мощностей по производству РЗЭ из лопарита Ловозерского месторождения. При всех очевидных преимуществах этого проекта недостатком является диспропорция получаемого и требуемого на рынке спектра РЗЭ. Второе - получение РЗМ из апатита Хибинского месторождения, в котором заключено около 60 \% балансовых запасов РЗЭ России, однако существует технологическая проблема безотходного получения РЗЭ из апатита, в результате чего с государственного баланса ежегодно списывается до 70 тыс. т РЗО. При этом варианте не решается проблема обеспечения России ниобием.

Первые два варианта требуют создания целых цепочек перерабатывающих предприятий, реанимацию старых или организацию новых мощностей, в то время как вариант быстрого раз-

$$
-129-
$$


вития российской РЗМ-промышленности за счет объектов Томторского рудного поля (в первую очередь, участок Буранный) является наиболее предпочтительным в основном из-за их уникальности по ресурсам, потенциальным запасам и соотношения в томторских рудах лантаноидов цериевой и иттриевой групп.

Разведанный участок Буранный характеризуется одними из самых высоких в мире параметрами полезных компонентов в руде. Запасы кондиционных руд по борту $1 \% \mathrm{Nb}_{2} \mathrm{O}_{5}$ по категориям $\mathrm{B}+\mathrm{C}_{1}$ составляют 42,7 млн т, в т. ч. $\mathrm{Nb}_{2} \mathrm{O}_{5}-1,3$ млн т, $\mathrm{TR}_{2} \mathrm{O}_{3}-3,2$ млн т. Государственным балансом учтены запасы 10 оксидов ( $\mathrm{Nb}, \mathrm{Y}, \mathrm{Sc}, \mathrm{La}, \mathrm{Ce}, \mathrm{Pr}, \mathrm{Nd}, \mathrm{Sm}, \mathrm{Eu}$ и Ti) по категориям $\mathrm{B}+\mathrm{C}_{1}$, для открытой отработки по борту $\mathrm{Nb}_{2} \mathrm{O}_{5} 3,5 \%$ в объеме 1,2 млн т. Средние содержания в балансовых рудах: $\mathrm{Nb}_{2} \mathrm{O}_{5}-6,71 \%, \mathrm{Y}_{2} \mathrm{O}_{3}-0,6 \%$; $\mathrm{Sc}_{2} \mathrm{O}_{3}-0,05 \%, \mathrm{TR}_{2} \mathrm{O}_{3}-9,5 \%$ (на отдельных флангах $12 \%$ ) [9-12].

На Томторском месторождении за счет средств федерального бюджета силами ГУГГП «Якутскгеология» в 2014-2016 гг. проведен комплекс оценочных работ на участках Северный и Южный. В результате получен существенный прирост запасов ниобия, скандия и редкоземельных металлов. Кроме того, в ходе оценки обращено особое внимание на значительные концентрации остродефицитных металлов, таких как марганец и др., приуроченных к Томторскому рудному полю. Показано также, что в его пределах может быть установлено золотоплатиновое оруденение [13, 14].

Учитывая то, что цены на индивидуальные РЗЭ различаются более чем на 1-2 порядка, а наиболее значительны эти различия для $\mathrm{TR}_{\mathrm{Ce}}$, с одной стороны, и $\mathrm{TR}_{\mathrm{Y}}$ и $\mathrm{Sc}-\mathrm{c}$ другой, инвестиционная привлекательность каждого из участков Томторского рудного поля очень зависит от содержания в них относительной доли наиболее ценных продуктов и, прежде всего, средних и тяжелых лантаноидов, а также $\mathrm{Y}$ и $\mathrm{Sc}$, которые дают основной вклад в стоимость товарной продукции.

\section{Томтор - ключ к решению проблемы}

Как и в других карбонатитовых массивах, в пределах Томтора редкие элементы (Nb, Y, $\mathrm{Sc}, \mathrm{TR})$ образуют промышленные концентрации. При этом отчетливо наблюдается рост концентрации $\mathrm{Nb}, \mathrm{Y}, \mathrm{Sc}$ и TR от карбонатитов к гипергенным (Fe-P) и далее к эпигенетически измененным рудам. На фоне типичных для массивов ультраосновных щелочных комплексов

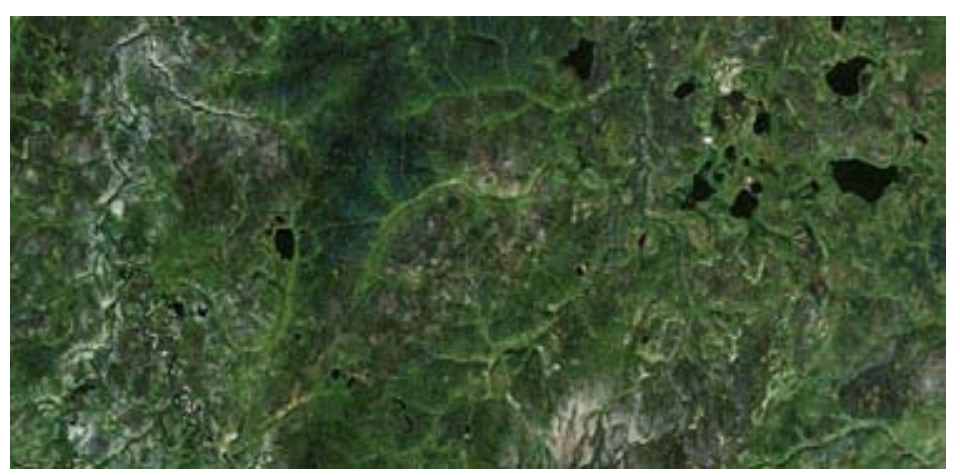

Рис. 1. Месторождение «Томтор» на спутниковом снимке. Координаты: СШ 7103'; ВД 116 $30^{\prime}$ 
(УЩК) концентраций $\mathrm{Nb}_{2} \mathrm{O}_{5}$ в силикатных породах $(0,05 \%)$ повышенные значения наблюдаются в коренных карбонатитах и их брекчиях до 0,5-1,5 \%, но наиболее существенно они повышаются в гипергенном комплексе (табл. 3) [15-17].

Гипергенный комплекс массива Томтор, сложенный $\mathrm{Fe}-\mathrm{P}-\mathrm{Nb}-\mathrm{TR}-$ рудой, проявляет отчетливую зональность: на карбонатитах залегает лимонит-франколитовый горизонт, который кверху сменяют лимонитовый и сидеритовый горизонты. Венчает разрез наиболее рудоносная переотложенная, эпигенетически измененная часть разреза, сложенная пирохлор-монациткрандаллитовыми рудами. Относительно невысокие концентрации рудных элементов в коренных породах (0,2-1 \%) достигают максимумов (до 40 \%) в эпигенетически преобразованных разновидностях. Концентрации $\mathrm{Nb}_{2} \mathrm{O}_{5}$ и $\mathrm{TR}_{2} \mathrm{O}_{3}$ возрастают от 1 до 10-25 \% соответственно. Уникальные комплексные $\mathrm{Nb}-\mathrm{Y}-\mathrm{Sc}-\mathrm{TR}$-руды пирохлор-монацит-крандаллитового состава Томтора, согласно нашим прежним данным, характеризуются обычным для кор карбонатитов цериевым составом лантаноидов $-\mathrm{La}+\mathrm{Ce}+\mathrm{Nd}+\mathrm{Pr}$ составляют в сумме около $92 \%$. При этом большинством исследователей подчеркивалось, что повышенная $\mathrm{Y}-\mathrm{Sc}-$ носность обусловлена повышенным уровнем концентрации TR и Th $[16,19,20]$.

Уникальные параметры руды обусловливают чрезвычайно высокую стоимость получаемой из нее товарной продукции: в зависимости от ассортимента она варьирует от 4 тыс. дол. (при получении продукции первого передела - карбонатов Р3Э, оксидов $\mathrm{Nb}, \mathrm{Y}$ и Sc) до 20 тыс. дол. (при получении высокочистых металлов и изделий на их основе). Во втором случае основная стоимость может быть получена за счет $\mathrm{Y}, \mathrm{Sc}, \mathrm{Nb}$ и дорогостоящих лантаноидов $-\mathrm{Nd}, \mathrm{Eu}$, Dу и Pr.

Кроме того, установлено, что в блоках, обогащенных Y и тяжелыми лантаноидами, нарушается установленная в ходе разведочных работ стабильная корреляция между TR и $\mathrm{Y}$ и $\mathrm{Sc}$. В этих блоках появляется несвойственная рудам корреляция $\mathrm{Y}$ и $\mathrm{Zr}, \mathrm{Sc}$ и $\mathrm{Zr}$. Минералогогеохимические исследования показывают, что в рассматриваемых блоках появляется эпи-

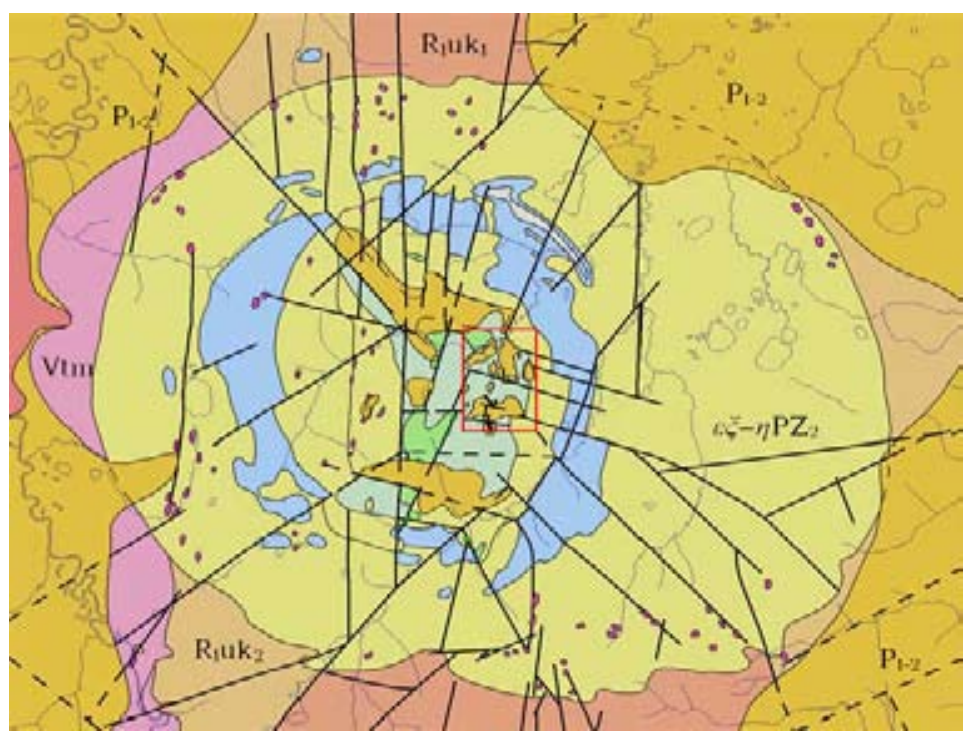

Рис. 2. Геологическая карта Томторского рудного поля [16] 
генетический циркониевой ксенотим, Y-Zr-минерал, в составе РЗЭ которого присутствуют или преобладают средние и тяжелые лантаноиды. Впервые это было отмечено совместными исследованиями геологов Якутии и ученых из ВИМСа [18-21]. Установлено, что структурнотекстурная позиция Zr-ксенотима в богатых рудах указывает на его приуроченность к одному из поздних эпизодов эпигенетических преобразований руд, который сопровождался их перекристаллизацией и развитием вокруг струевидных и полосчатых выделений Zr-ксенотима зон отложения алюмофосфатов ряда гояцит-флоренсит и минералов титана (ильменрутила). Таким образом, наложение эпигенетической стадии на гипергенно-измененные и переотложенные продукты выветривания карбонатитов приводит к смещению состава РЗЭ в сторону $\mathrm{Y}$, средних и тяжелых лантаноидов, значительному росту концентраций Sc и Th в рудах [1821].

\section{Новые возможности Томторского рудного поля}

Проведенный нами в последнее время анализ выявляет в уникальных томторских рудах более значительную вариативность состава TR, в результате чего при средней величине $\mathrm{Ce} / \mathrm{Y}$ отношения по разведочным пробам Буранного участка на уровне 10-12 в отдельных сплошных пересечениях рудного тела это отношение повышается до 80 и опускается до 1,0-2,0. Таким образом, на отдельных участках содержания Се и Y, как и содержания TRCe и TRY, становятся практически сопоставимыми. Содержания $\mathrm{Y}_{2} \mathrm{O}_{3}$ в них растут до $2 \%$ при средних концентрациях по месторождению 0,5 \%, а отношения $\mathrm{Ln}_{2} \mathrm{O}_{3} / \mathrm{Y}_{2} \mathrm{O}_{3}$ снижаются до 4,8-8,0 по сравнению со средними значениями для руд на уровне 20-30. Отношения Се/Ү понижаются до минимума 2,0-6,0, что означает выравнивание доли LnCe и LnY. Это создает принципиально новую ситуацию, при которой извлечение наиболее дефицитных и ценных тяжелых лантаноидов может быть экономически выгодным, несмотря на невысокие концентрации, и кардинально повлиять на стоимость всей товарной продукции. Результаты, полученные в последние годы, показывают, что в пределах участка месторождения могут быть выделены целые блоки таких руд объемом 1 млн т руды, аномально обогащенные Y, Sc и LnY по сравнению со средними значениями для месторождения. Параметры одного такого блока, полученные по трем буровым пластопересечениям рудного тела, приведены в табл. 3.

Таблица 3. Параметры Y-Sc оруденения (западный фланг участка Буранный) [15]

\begin{tabular}{|c|c|c|c|c|c|}
\hline №o п/П & Параметры & Скв. 5655 & Скв. 5755 & Скв. 5855 & Среднее \\
\hline 1 & $\mathrm{~h}, \mathrm{M}$ & 30,4 & 23,8 & 31,5 & 28,6 \\
\hline 2 & $\mathrm{~m}, \mathrm{M}$ & 12,6 & 12,4 & 10,1 & 11,7 \\
\hline 3 & $\mathrm{Nb}_{2} \mathrm{O}_{5} \%$ & 9,47 & 9,08 & 5,85 & 8,13 \\
\hline 4 & $\mathrm{Y}_{2} \mathrm{O}_{3} \%$ & 2,223 & 2,067 & 1,668 & 2,00 \\
\hline 5 & $\mathrm{Sc}_{2} \mathrm{O}_{3} \%$ & 0,136 & 0,150 & 0,108 & 0,13 \\
\hline 6 & $\mathrm{Ln}_{2} \mathrm{O}_{3} \%$ & 10.65 & 14,28 & 13,41 & 12,78 \\
\hline 7 & $\mathrm{Ln}_{2} \mathrm{O}_{3} / \mathrm{Y}_{2} \mathrm{O}_{3}$ & 4,79 & 6,91 & 8,04 & 6,44 \\
\hline
\end{tabular}

Примечание: $\mathrm{h}$ - глубина залегания кровли рудного тела, $\mathrm{m}$ - мощность рудного тела, $\mathrm{Ln}_{2} \mathrm{O}_{3}-$ содержание суммы оксидов лантаноидов. 
Тесное взаимное прорастание главных рудных и породообразующих минералов обусловило принципиальную невозможность обогащения руды механическими методами, в результате чего не удавалось получить конечных продуктов. Это является следствием недостаточности исследований и выдвинуло вперед гидрометаллургию. Разработанная химическая технология (работы специалистов Института химии и химической технологии СО РАН, Красноярск, д.Х.н. В.И. Кузьмин) предусматривает щелочное вскрытие исходной руды, последующее сульфатное разложение кека и экстракцию раствора с получением в товарную продукцию оксидов редких элементов: Nb, Sc, Y, Ce, La, Pr, Nd, Sm, Eu, а также Ti [22-25].

Технология выгодна тем, что объем товарной продукции с 1 т руды превышает 1 т, а объем отходов не превышает 0,5 т. Радиоактивные элементы (U, Th) концентрируются в продукт объемом около 60 кг. Разработана и альтернативная сернокислотная обработка исходной руды. Заводские испытания не проводились, и это необходимо выполнить на первом этапе освоения месторождения, для этого в г. Железногорске (Красноярский край,) 250 т руды готовы к испытаниям на площадке Железногорского ГХК. Дальнейшие исследования показали возможность расширить эту линейку до 20 товарных продуктов, включая наиболее ценные оксиды тяжелых лантаноидов. Это позволяет говорить о возможностях получения практически всей линейки Р3Э (14 элементов), а также $\mathrm{Sc}, \mathrm{Y}$ и Nb из одного сырьевого источника, что выдвигает Томтор на первый план по сравнению с другими сырьевыми источниками РЗЭ в России. Уникальность технологии в том, что в полезную переработку вовлекается более 75 \% компонентов руды при отсутствии необходимости ее предварительного обогащения, так как фактически руды могут рассматриваться как природный черновой концентрат [5, 26-28].

\section{Альтернативная технология}

Однако дороговизна гидрометаллургической технологии при незначительных горнотранспортных издержках предприятия диктует поиски новых методов извлечения полезных компонентов из уникальных руд, которые могут быть разработаны на основе электроплавки исходной руды. Этот способ разработан для получения металлов, чистых от примесей и газов. Его можно использовать и для плавки исходной руды при существенном удешевлении процесса получения промпродуктов. Суть его состоит в том, что тепло выделяется за счет прохождения тока через жидкий шлак и разогрев руды происходит в мягком режиме $\left(\mathrm{t} \approx 1500-1700{ }^{\circ} \mathrm{C}\right)$, при котором можно использовать Сu-стальные нерасходуемые электроды, позволяющие не загрязнять получаемые металлы посторонними примесями.

Сотрудниками Института геологии и минералогии СО РАН (А.В. Толстов) совместно с работниками АО «Лантан» (Бердск, Новосибирская область) проведен эксперимент по восстановлению $\mathrm{Fe}$ и $\mathrm{Nb}$ из томторской руды, для чего использовался $\mathrm{Cu}$-стальной электрод и тигель, футерованный магнезитовой крошкой марки ППР-88. Нижний электрод представлял собой охлаждаемую затравку D300 мм с переходным стержнем D40 мм и высотой 70 мм. Процесс начинался через твердый старт металлическим стержнем диаметром 50 мм и высотой 80 мм, массой 2,3 кг. После расплавления порошка $\mathrm{CaF}_{2}$ сплавления металлического стержня вводился нерасходуемый электрод.

При установлении стабильного тока 4000 А засыпали руду по 0,5 кг. Совместно с рудой засыпали алюминий из расчета стехиометрий по $\mathrm{Fe}$ и $\mathrm{Nb}$. После окончания плавки жидкость 


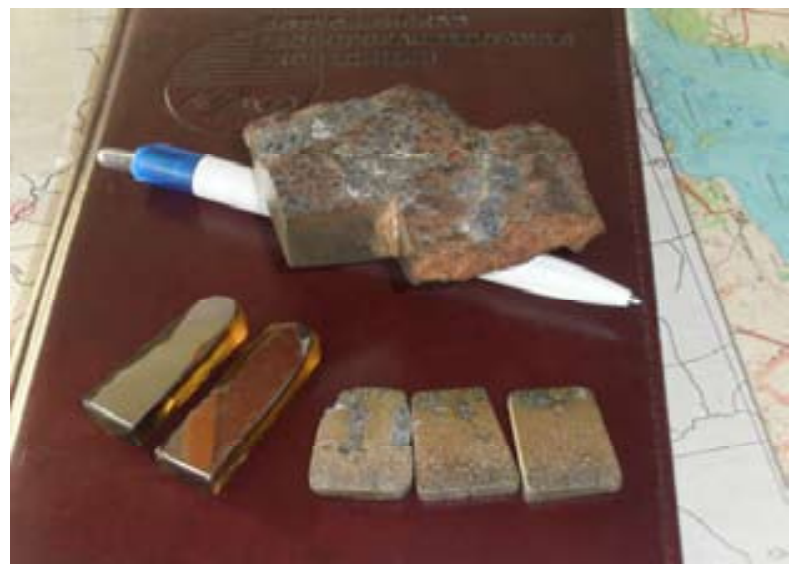

Рис. 3. Результаты электроплавки руды Томтора: слева - феррониобий, справа - редкоземельный шлак

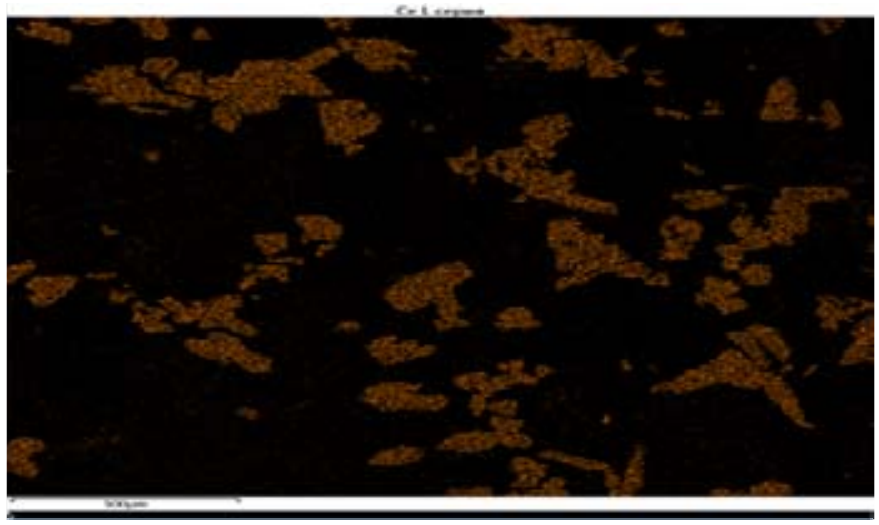

Рис. 4. Обособления РЗМ (светлое), образующиеся в шлаке элетроплавки (в лучах Се)

сливалась в тигель, покрытый известью. После охлаждения металл и шлак легко отделялись друг от друга механически.

Полученные металл и шлак проанализированы раздельно: металл практически представляет собой феррониобий с различными соотношениями железа и ниобия при повышенном для кондиционного продукта содержании фосфора, что служит дальнейшей задачей исследований. В то же время шлак содержит около 10-15 \% РЗЭ, является богатой рудой и нуждается в дальнейшей переработке (рис. 3).

Результаты позволили предложить новую схему, при которой шлак даже после дробления и классификации может быть разделен на богатую редкоземельную (более 20 \% РЗЭ) и силикатную части (рис. 4). Дальнейшими работами предполагается получение из шлака товарных редкоземельных продуктов, что, на наш взгляд, вполне реально, поскольку только одна расситовка дробленого материала дает обогащение в разных фракциях дробления по Y, La, Ce и др. Р3Э в два и более раз. Включение в процесс гравитационных и флотационных методов, вероятно, позволит получать кондиционные концентраты РЗЭ и существенно удешевить последующую стадию технологии [28, 29]. 


\section{Выводы}

Проблема обеспечения России РЗМ носит стратегический характер и имеет несколько вариантов решения. Томторское рудное поле ввиду его комплексности и уникальности параметров на РМ и Р3 представляет собой выдающийся объект, который может удовлетворить любые потребности отечественной промышленности и имеет существенный экспортный потенциал. Разработанная химическая технология позволяет получать полную линейку РЗМ, включая Ү, $\mathrm{Sc}$ и $\mathrm{Nb}$ из одного источника.

Выполненные исследования дали возможность выявить и предложить к первоочередному освоению отдельные части участка Буранный (западный фланг), уникально обогащенные наиболее дорогими РЗЭ - тяжелыми лантаноидами Ү группы.

Электроплавка исходной руды может существенно снизить себестоимость получения конечной продукции - феррониобия и полной линейки РЗМ, включая наиболее дефицитные и дорогостоящие лантаноиды, и обеспечить максимальный экономический эффект.

Дальнейшие исследования должны быть направлены на изучение возможностей получения чистой продукции РЗЭ (металлов и соединений на их основе), а также на разработку экономической модели регулирования цикла переработки и селективного получения редкоземельной продукции в зависимости от изменения конъюнктуры рынка (опциональная балансирующая модель переработки руды и получения РЗМ).

\section{Список литературы}

1. Кудрин В.С., Усова Т.Ю., Чистов Л.Б. Редкоземельные металль России: состояние, перспективы освоения и развития минерально-сырьевой базы. М.: ВИМС 2000. 103 с. [Kudrin V.S., Usova T.Yu., Chistov L.B. Rare earth metals Russia: state and development prospects of the mineral resource base. M.: VIMS 2000. 103 p. (in Russian)]

2. Крюков В.А., Толстов А.В., Самсонов Н.Ю. Стратегическое значение редкоземельных металлов в мире и в России. ЭКО 2012, 11, 5-16 [Kryukov V.A., Tolstov A.V., Samsonov N.Yu. The strategic importance of rare earths in the world and in Russia. ECO 2012, 11, 5-16 (in Russian)]

3. Похиленко Н.П., Крюков В.А., Толстов А.В., Самсонов Н.Ю. Томтор как приоритетный инвестиционный проект обеспечения России собственным источником редкоземельных элементов. ЭКО 2014, 2, 22-35 [Pokhilenko N.P., Kryukov V.A., Tolstov A.V., Samsonov N.Yu. Tomtor as a priority investment project of ensuring Russia's own source of rare earth elements. ECO 2014, 2 , $22-35$ (in Russian)]

4. Толстов А.В., Похиленко Н.П. Перспективы освоения Томторского месторождения комплексных ниобий-редкоземельных руд. ЭКО 2012, 11, 17-27 [Tolstov A.V., Pokhilenko N.P. Prospects of development of the field of complex niobium-rare earth ores on Tomtor field. ECO 2012, 11, 17-27 (in Russian)]

5. Толстов А.В., Самсонов Н.Ю. Томтор: геология, технология, экономика. ЭКО 2014, 2 , 36-44 [Tolstov A.V., Samsonov N.Yu. Tomtor: geology, technology, economy. ECO 2014, 2, 36-44 (in Russian)]

6. Толстов А.В., Похиленко Н.П., Лапин А.В., Крюков В.А., Самсонов Н.Ю. Инвестиционная привлекательность Томторского месторождения и перспективы ее повышения. Разведка и охрана недр 2014, 9, 25-30 [Tolstov A.V., Pokhilenko N.P., Lapin A.V., Kryukov V.A., Samsonov N.Yu. 
Investment attractiveness Tomtor field and its prospects improve. Exploration and subsoil protection 2014, 9, 25-30 (in Russian)]

7. Толстов А.В. Проблемы геолого-экономической оценки уникальных руд Томторского месторождения. Стратегия использования и развития минерально-сырьевой базы редких металлов России в ХХІ веке. Тезисы докладов. М.: ВИМС, 1998, 135-137 [Tolstov A.V., Problems of geological and economic evaluation of the unique ore deposits Tomtor. In Abstracts «Use strategy and development of the mineral resource base of rare metals Russia in the XXI century». M.: VIMS, 1998, 135-137 (in Russian)]

8. Похиленко Н.П., Крюков В.А., Толстов А.В., Самсонов Н.Ю. Создание сильной редкоземельной промышленности России: без госкорпораций не осилить. ЭКО 2016, 8, 25-36 [Pokhilenko N.P., Kryukov V.A., Tolstov A.V., Samsonov N.Yu. Creating a strong rare earth industry in Russia: state corporations without not overpower. ECO 2016, 8, 25-36 (in Russian)]

9. Энтин А.Р., Зайцев А.И., Ненашев Н.И., Василенко В.Б., Орлов А.И., Тян О.А., Ольховик Ю.А., Ольштынский С.И., Толстов А.В. О последовательности геологических событий, связанных с внедрением Томторского массива ультраосновных щелочных пород и карбонатитов (северо-западная Якутия). Геология и геофизика 1990, 12, 42-45 [Entin A.R., Zaitzev A.I., Nenashev N.I., Vasilenko V.B., Orlov A.I., Tyan O.A., Olkhovik Yu.A., Olshtinky S.I., Tolstov A.V. On the sequence of geological events associated with the introduction of Tomtor alkaline ultrabasic rocks and carbonatites (Northwest Yakutia). Geology and geophysics 1990, 12, 42-45 (in Russian)]

10. Толстов А.В., Энтин А.Р., Тян О.А. Промышленные месторождения в карбонатитовых комплексах Якутии. Якутск: Изд-во ЯНЦ СО РАН. 1995, 168 с. [Tolstov A.V., Entin A.R., Tyan O.A. Industrial deposits in carbonatite complexes of Yakutia. Yakutsk: Yakut Research Center SB RAS, 1995, 168 p. (in Russian)]

11. Кравченко С.М., Беляков А.Ю., Кубышев А.И., Толстов А.В. Скандиево-редкоземельноиттриево-ниобиевые руды - новый тип редкометалльного сырья. Геология рудных месторождений 1990, T. 32, 1, 105-109 [Kravchenko S.M., Belyakov A.Yu., Kubishev A.I., Tolstov A.V. Scandium-yttrium-rare earth-niobium ores as a new type of rare metal raw materials. Geology of ore deposits 1990, v. 32, 1, 105-109 (in Russian)]

12. Лапин А.В., Толстов А.В. Окислительный и восстановительный этапы формирования зоны гипергенеза карбонатитов и их рудоносность. Геология рудных месторождений 1991, 4, 81-91 [Lapin A.V., Tolstov A.V. The oxidation and reduction stages of formation of the supergene zone of carbonatite and its ore-bearing. Geology of ore deposits 1991, 4, 81-91 (in Russian)]

13. Толстов А.В., Дедюхин А.Н., Похиленко Н.П. Новые возможности получения редкоземельных металлов из эпигенетически измененных руд кор выветривания карбонатитов. Актуальные вопросы получения и применения Р3М 2014, 29-32 [Tolstov A.V., Dedyukhin A.N., Pokhilenko N.P. New opportunities for rare earth metals from ores epigenetically altered carbonatite weathering crusts. In collection of materials of the International scientific-practical conference «Topical issues of making and using REM» 2014, 29-32 (in Russian)]

14. Толстов А.В. Новые перспективы Томторского рудного поля. Геология и минеральносырьевые ресурсы Северо-Востока России. 31 марта-2 апреля 2015 г. Якутск: Издательский дом СВФУ 2015, 500-506 [Tolstov A.V. New perspectives of Tomtor REE-ore field. Materials of All- 
Russian scientific-practical conference "Geology and mineral resources of the North-East of Russia», March 31-April 2 2015. Yakutsk: North-Eastern Federal University 2015, 500-506 (in Russian)]

15. Толстов А.В., Лапин А.В., Похиленко Н.П., Овчинников К.В. Скандий и иттрий Томторского рудного поля. Цветная металлургия 2015, 4, 37-43 [Tolstov A.V., Lapin A.V., Pokhilenko N.P., Ovchinnikov K.V. Scandium and yttrium of Tomtor REE-ore field. Non-ferrous metallurgy 2015, 4, 37-43 (in Russian)]

16. Толстов А.В., Тян О.А. Геология и рудоносность массива Томтор. Якутск, Изд-во ЯНЦ CO PAH. 1999, 164 c. [Tolstov A.V., Tyan O.A. Geology and ore of massive Tomtor. Yakutsk: Yakut Research Center SB RAS. 1999, 164 p. (in Russian)]

17. Толстов А.В. Особенности минералогии и геохимии апатит-магнетитовых руд массива Томтор (Северо-Западная Якутия). Геология и геофизика 1994, 9, 91-100 [Tolstov A.V. Features mineralogy and geochemistry of apatite-magnetite ores of massive Tomtor (Northwest Yakutia). Geology and geophysics 1994, 9, 91-100 (in Russian)]

18. Толстов А.В., Гунин А.П. Комплексная оценка Томторского месторождения. Вестник Воронежского государственного университета. Серия: Геология 2001, 11, 144-160 [Tolstov A.V., Gunin A.P. Comprehensive assessment of Tomtor REE-field. Bulletin of Voronezh State University. Series: Geology 2001, 11, 144-160 (in Russian)]

19. Толстов А.В. Главные рудные формаџии Севера Сибирской платформы. М.: ИМГРЭ 2006. 212 c. [Tolstov A.V. The main ore formations of the North of the Siberian Platform. M.: Institute of Mineralogy, Geochemistry and Crystal Chemistry of Rare Elements 2006. 212 p. (in Russian)]

20. Лапин А.В., Толстов А.В. Минерагения кор выветривания карбонатитов. М.: ГЕОKAPT, ГЕОC 2011. 308 c. [Tolstov A.V., Lapin A.V. Minerageny carbonatite weathering crusts. Methodological guide. M.: GEOMAP, GEOS 2011. 308 p. (in Russian)]

21. Фролов А.А., Толстов А.В., Белов С.В. Карбонатитовые месторождения России. М. 2003. 493 c. [Frolov A.A., Tolstov A.V., Belov S.V. Carbonatite deposits Russia M. 2003. 493 p. (in Russian)]

22. Лазарева Е.В., Жмодик С.М., Добрецов Н.Л., Толстов А.В., Щербов Б.Л., Карманов Н.С., Герасимов Е.Ю., Брянская А.В. Главные рудообразующие минералы аномально богатых руд месторождения «Томтор» (Арктическая Сибирь). Геология и геофизика 2015, Т. 56(6), 10801115 [Tolstov A.V., Zhmodik S.M., Dobretsov N.L., Scherbov B.L., Karmanov N.S., Gerasimov E.Yu., Bryanskaya A.V. The main ore-forming minerals abnormally rich ore deposits Tomtor (Arctic Siberia). Geology and geophysics 2015, v. 56(6), 1080-1115 (in Russian)]

23. Коноплев А.Д., Толстов А.В., Васильев А.Т., Нечелюстов Г.Н., Кузьмин В.И., Скляднева В.М., Дубинчук В.Т., Коноплева Е.В., Сидоренко Г.А. Особенности локализации редкометального оруденения на месторождении Томтор. Редкометально-урановое рудообразование в осадочных породах. M., 1995, 223-241 [Konoplev A.D., Tolstov A.V., Vasiliev A.T., Nechelyustov G.N., Kuzmin V.I., Sklyadneva V.M., Dubinchuk V.T., Konopleva E.V., Sidorenko G.A. Localization rare metal mineralization at the deposit Tomtor. In the collection of scientific works «Rare metals and uranium mineralization in sedimentary rocks». M., 1995, 223-241 (in Russian)]

24. Толстов А.В., Коноплев А.Д., Кузьмин В.И. Особенности формирования уникального редкометалльного месторождения Томтор и оценка перспектив его освоения. Разведка и охрана недр 2011, 6 20-25 [Tolstov A.V., Konoplev A.D., Kuzmin V.I. Features of formation of a unique and 
rare metal Tomtor deposit and assessment of the prospects of its development. Exploration and subsoil protection 2011, 6 20-25 (in Russian)]

25. Рылов Д.А. Слепцов А.П., Толстов А.В. Перспективы и способы отработки Томторского рудного поля. Фундаментальные и прикладные вопросы горных наук 2016, 3, 168-175 [Rylov D.A., Sleptzov A.P., Tolstov A.V. Prospects and ways of mining the ore field Tomtor. Fundamental and Applied Problems of Mining Sciences 2016, 3, 168-175 (in Russian)]

26. Делицын Л.М., Мелентьев Г.Б., Толстов А.В., Магазина Л.А., Самонов А.Е., Сударева С.В. Технологические проблемы Томтора и их решение. Редкие земли 2015, 2(5), 164-179 [Delitzin L.M., Melentiev G.B., Tolstov A.V., Magazina L.A., Samonov A.E., Sudareva S.V. Technological problems and solutions of Tomtor deposit. Rare earth 2015, 2(5), 164-179 (in Russian)]

27. Слепцов А.П., Толстов А.В., Баранов Л.Н. Новый взгляд на полезные ископаемые Томторского рудного поля. Геология и минерально-сырьевые ресурсы Северо-Востока России. 2016, 271-275 [Sleptzov A.P., Tolstov A.V., Baranov L.N. A new vew for minerals of Tomtor ore field. In the collection: Geology and mineral resources of the North-East of Russia. Proceedings of the VI All-Russian scientific-practical conference 2016, 271-275 (in Russian)]

28. Шепелев Н.В., Тетерин М.А. Установка электрошлакового переплава, сварки и наплавки металла. Патент №2247163 [Shepelev N.V., Teterin M.A. Installation of electro-slag remelting, metal welding and surfacing. Patent №2247163 (in Russian)]

29. Шепелев Н.В., Набиев К.Ф., Толстов А.В., Лобарев И.В. Использование РЗМ для легирования стали при электрошлаковом литье. Актуальные вопросы получения и применения PЗМ-2015. М.: Институт ГИНЦВЕТМЕТ 2015, 172-184 [Shepelev N.V., Nabiev K.F., Tolstov A.V., Lobarev I.V. The use of rare-earth metals for alloying of steel in electroslag casting. The collection of materials of the International Conference "Topical issues of making and using the REM-2015». M.: Institute GINZVETMET 2015, 172-184 (in Russian)]. 